\title{
The logging of a world heritage site: Wood Buffalo National Park, Canada
}

\author{
by Kevin Timoney ${ }^{1}$
}

Logging of the riparian old-growth white spruce forests of Wood Buffalo National Park took place from 1951 to 1991. Operations were conducted in the Peace River valley in the Big Island block (Timber Berth (TB) 408) and the Peace Delta block, and in the Athabasca River valley. Approximately $70 \%$ of the pre-logging old-growth riparian forests have been lost to logging, leaving a remnant of $\sim 100 \mathrm{~km}^{2}$ in the park, of which $\sim 30 \mathrm{~km}^{2}$ are found in TB408. A minimum of $100 \mathrm{~km}^{2}$ has been logged from TB408. Natural regeneration has failed on $93 \%$ of these lands ( $9300 \mathrm{ha}$ ). The logging agreement, which expired in 1981, was renewed in 1983, the same year in which Wood Buffalo National Park was declared a UNESCO World Heritage Site. The history of logging in Wood Buffalo National Park is characterized by government mismanagement and industrial malpractice. There was never legal authority to log in Wood Buffalo National Park, as it contravened the National Parks Act (1930). The need for restoration is discussed.

Key words: boreal, forestry, management, Peace River, riparian, white spruce, Wood Buffalo National Park
L'exploitation des vieilles forêts riveraines d'épinette blanche du parc national Wood Buffalo a eu lieu de 1951 à 1991. Les opérations se sont déroulées dans le bloc de Big Island (Timber Berth (TB) 408) de la vallée de la rivière Peace et dans le bloc du delta de la Peace, et dans la vallée de la rivière Athabasca. Près de $70 \%$ des vieilles forêts riveraines antérieures à l'exploitation ont été récoltées, laissant une reliquat de près de $100 \mathrm{~km}^{2}$ dans le parc, dont quelque $30 \mathrm{~km}^{2}$ que l'on retrouve dans le TB 408. Au moins $100 \mathrm{~km}^{2}$ ont été exploités dans le TB 408. La régénération naturelle est absente dans $93 \%$ des cas sur ces territoires (9 300 ha). Le contrat d'exploitation, venu à échéance en 1981, a été renouvelé en 1983, la même année où l'UNESCO a décreté que le parc national de Wood Buffalo devenait un site du patrimoine mondial. L'histoire de l'exploitation forestière du parc national de Wood Buffalo est caractérisée par la mauvaise gestion gouvernementale et les mauvaises pratiques de l'industrie. Il n'y a jamais eu d'autorisation légale permettant de procéder à l'exploitation forestière du parc national de Wood Buffalo, puisque que cela est en contradiction avec la Loi sur les Parcs nationaux (1930). Les éléments relatifs à la restauration sont discutés.

Mots clés: boréal, foresterie, aménagement, rivière Peace, riverain, épinette blanche, parc national Wood Buffalo
Calvin: The secret to happiness is short-term, stupid self-interest!

Hobbes: I'm not sure I can stand so much bliss.

Calvin: Careful! We don't want to learn anything from this.

Calvin and Hobbes

\section{Introduction}

Wood Buffalo National Park was established in 1922 in order to protect the endangered wood bison (Lothian 1976). Logging of the riparian white spruce (Picea glauca [Moench] Voss) forests of Wood Buffalo National Park began under the Northern Administration Branch of the Dept. of Northern Affairs and National Resources (Olsen 1992). Their mandate was economic growth, and thus Wood Buffalo was viewed as having little value outside of resource extraction. Logging began in 1951 on the Peace River north of the Peace-Athabasca Delta (Timber Berth 253), with wood destined for the Eldorado Uranium Mine on the north shore of Lake Athabasca (Potyondi 1979). The National Parks Act (National Parks Service 1930), which stated that "...Parks shall be maintained ... so as to leave them unimpaired..." was ignored. With logging by the Eldorado Mining and Refining Company underway by 1951, the fed-

Forest Ecologist, Tree Line Ecological Research Consultants, Sherwood Park, Alberta, Canada. eral government further promoted the development of industrial logging in Wood Buffalo (Flanagan 1992).

Bureaucrats identified two logging blocks along the Peace River (Big Island Block: Timber Berth 408; and the Peace Delta Block: Timber Berths 253, 367, 378, 396, and 408) and one on the Athabasca River (Athabasca Block: Timber Berth 503), all within Wood Buffalo National Park, and all in lowland alluvial white spruce ecosystems (Fig. 1). By the mid 1950s, all five berths, containing all the commercially valuable lowland white spruce forests, were leased and logging begun. The plan was to liquidate all the old-growth forests in Timber Berth 408 and elsewhere in the park: "Over the term of the Agreement, all accessible mature and overmature timber in the Berth will be harvested." (Swanson Lumber Company 1981). Due to the flat river valley and to winter logging, all these riparian forests were accessible.

By 1964, the Northern Administration Branch had tacitly admitted that its administration of Wood Buffalo had been a mistake: "...there is no practical way to resolve the dilemma of economic exploitation of this timber...", and thus began transfer of responsibilities to the Parks Branch, a process complete by 1969 (Potyondi 1979). Logging ended in the spring of 1991, with official closure in federal court in June 1992.

At least 10,000 ha have been logged from TB408, about twothirds of which were cut between 1980 and 1990 (Dempster and Associates 1990; Olsen 1992; Timoney 1995). This estimate is based on incomplete and dubious records, as most data are derived from log scaling data and cutblock maps provided by the logging companies. These records did not record wood 


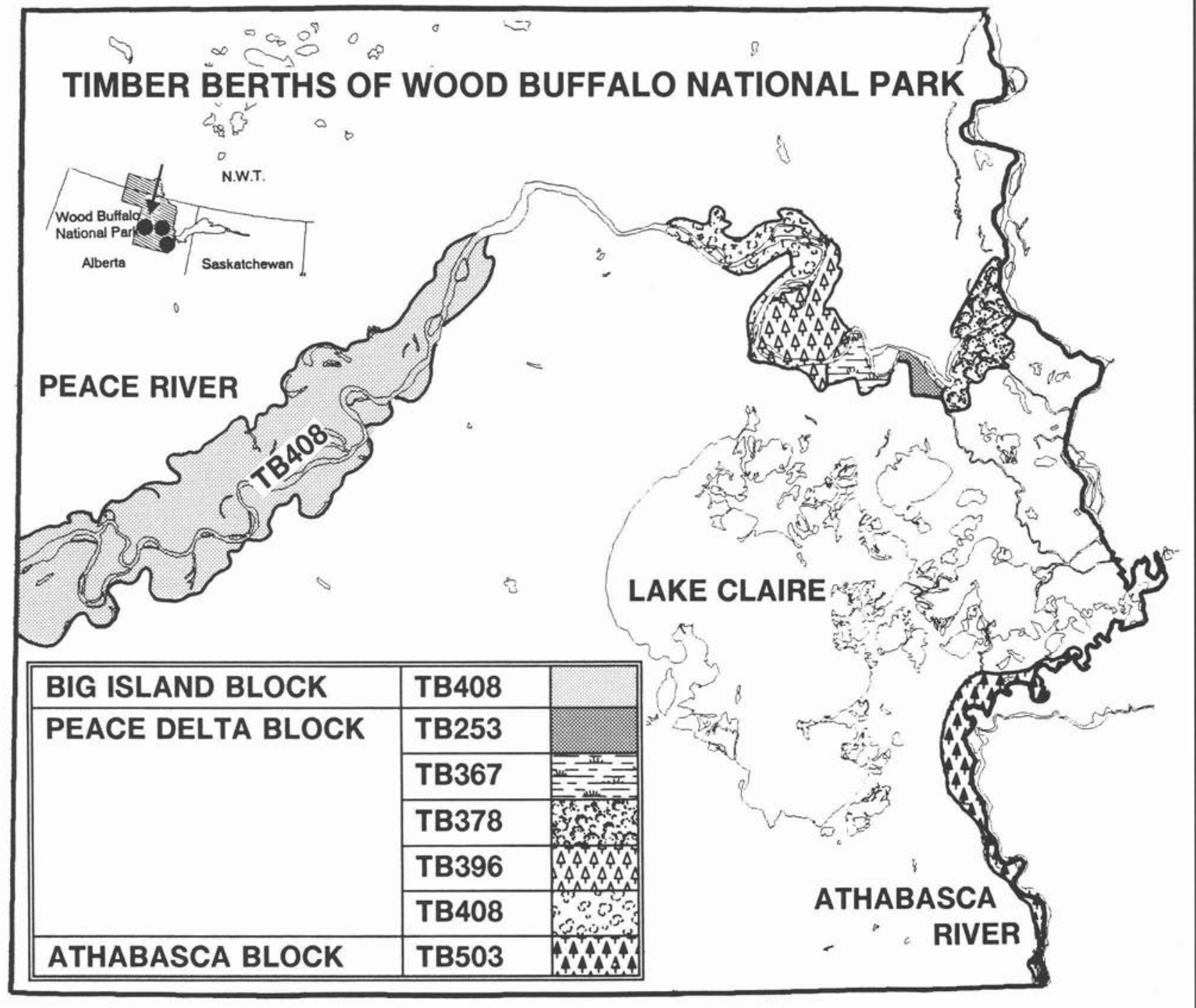

Fig. 1. Logging areas (timber berths) of Wood Buffalo National Park (after Ray 1961; Olsen 1992).

wasted or left, nor do they account for the tracts of noncommercial or mixedwood forests damaged or cut in pursuit of the spruce. Comparison of cutblock maps with actual area logged showed that forest companies routinely cut beyond the reported boundaries (Pearson Timberline 1991; Westhaver 1991; field observations). The total of 10,000 ha logged in TB408 is conservative.

\section{Boreal Riparian Old-growth White Spruce Forests}

The target of logging in Wood Buffalo was the alluvial lowland white spruce forests of the Peace and Athabasca Rivers. These forests are restricted to silt terraces of the major river valleys of northwestern Canada where spruce tree ages exceed 160 years (Timoney and Robinson 1996). In the absence of logging, succession in this ecosystem is driven largely by flooding, accumulation of sediment, and channel wandering (Annas 1977; Peterson 1981; Timoney and Robinson 1996). These oldgrowth forests contain the tallest known white spruce in the world $(40-46 \mathrm{~m})$, and are characterized by high structural and functional diversity (multiple age-structure, canopy gap dynamics, high degree of canopy roughness, tree-snag-log-buried wood succession; nursery logs, etc.) (Timoney and Robinson, 1996) and biological diversity (e.g. birds, vascular plants, mosses, lichens, mycorrhizal fungi, mammals) (Francis and Lumbis 1979; Meslow et al. 1981; Westworth and Associates 1990; Fairbarns 1991; Farr 1993; Marshall 1993; Timoney and Robinson, 1996). Fire plays only a minor role in such a flood-driven ecosystem (Annas 1977; Nanson and Beach 1977). Many old white spruce and balsam poplar forests in TB408 have maintained themselves through centuries; the age of the forest is not given by the oldest trees; the forest predates its oldest trees (Timoney and Robinson 1996).

The misconception that these forests were common boreal uplands extended as far as Jean Charest, Minister of Environment in the last term of the Mulroney government. In form letters to citizens concerned with the logging of Wood Buffalo, he wrote that the area being logged "represents only $1.1 \%$ of the park." It was misleading, however, to equate communities as dissimilar as riparian white spruce forests with 
boreal uplands and shrub wetlands. In reality, the area being logged was the largest and best remnant of riparian oldgrowth spruce forest in the park, a fact that the minister should have known.

These forests are of international significance, yet they remain the most intensively logged forest type in Alberta, northern British Columbia, and the Northwest Territories (Timoney and Robinson 1996). Only about $1000 \mathrm{~km}^{2}$ of these forests remain today, one-half of the total present in 1960 (Timoney 1995). Logging has ended in Wood Buffalo. Of the approximately 333 $\mathrm{km}^{2}$ of white spruce and white spruce - balsam poplar forests with stand ages $\geq 160$ years in Wood Buffalo prior to logging (Ray 1961), $\sim 70 \%$ of these forests have been lost. A remnant of perhaps $\sim 100 \mathrm{~km}^{2}$ of old-growth white spruce and white spruce - poplar forests exists in Wood Buffalo. The largest remaining tracts are found in the Peace Delta Block (airborne observations, September 1995), and in TB408 ( 30 km²) (Fig. 1) (Ray 1961; Timoney and Robinson 1996). The absence of an ecological land classification for the logged areas precludes a precise areal estimate. Outside park boundaries along both the Peace and Athabasca Rivers, liquidation continues today; clearcut logging has just begun on the Liard River; and logging on the Mackenzie River is planned (Timoney and Robinson 1996). In five to eight years all commercial riparian old-growth forests will be liquidated from the Slave River; the NWT Development Corporation then plans to move its sawmill to Ft. Liard for logging of the Liard River forests (Mark Bradley, NWT regional biologist, pers. comm. 1995). That recent progressive changes in forestry in other regions have not been adopted in the north speaks poorly of the way we value these forests (John Zasada, pers. commun. 1995).

\section{The Logging Agreement}

The agreement (Anonymous 1983) between the federal government and the logging company contained a number of important conditions (There were no ecological restoration or cleanup provisions):

Provision \#2. Inexplicably, crown timber fees were set at onetenth the rate paid on adjacent Alberta lands outside the park.

Provision \#7. The environment minister could apply a holdback in order to save certain ecologically significant areas from logging (up to $2 \%$ of the total area of the berth). Incredibly, Parks Canada did not use its protection holdback clause until 1990-1991.

Provision \#11. The operators could cut up to $400,000 \mathrm{~m}^{3}$ of timber each year. Such an annual allowable cut translates to about $16 \mathrm{~km}^{2}$ year ${ }^{-1}$ logged in an ecosystem that supported only about $129 \mathrm{~km}^{2}$ of commercial spruce and spruce - poplar forest prior to logging [areal pre-logging estimate after Ray (1961)]. The agreement, in effect, would have permitted the total liquidation of the old-growth forests in eight years. Since the minimum allowable tree age for logging was 160 years, the agreement prescribed a logging rate 20 times the rate at which the forests could replace themselves. In practice, the largest volume cut in a year (1988-1989 season) was $263,000 \mathrm{~m}^{3}$, equivalent to $10.5 \mathrm{~km}^{2}$.

Provision \#12. The operating ground rules would be those used in Alberta's Footner Lake forest [i.e., Alberta Timber Harvest Planning and Operating Ground Rules (Anonymous 1990)].
Provision \#20. The operator was to prevent damage to young growth or trees left standing (i.e. protect advance growth and residual trees).

Provision \#27. Minimum stand age for cutting was set at 160 years.

Provision \#31. The most critical of provisions was: “...the Operator shall be responsible for ... forest management techniques which will encourage the natural reforestation of the Area. This said management program shall be outlined in the Forest Management Plan and be subject to the approval of the Director." There is no evidence in the TB 408 records of any management plans that outline techniques to provide for natural spruce regeneration. Only one reference was found to spruce regeneration: "...Studies conducted by various agencies on the alluvial plain indicate that White Spruce regeneration is very poor. This is due in large part to the deep humus layer...silvicultural treatments could provide a suitable seedbed; however, it is the desire of Parks Canada to restrict any further disturbance...Due to this policy, the plan does not concern itself with forest renewal." (Swanson Lumber Company 1981) (No mention is made of the primary reason for failure of spruce regeneration: death of all spruce trees and destruction of advance growth). The land was not left in a state that encouraged natural reforestation.

Provision \#31. The operator was required to conduct reforestation surveys two and seven years after logging any area (26 years of logging $=26$ two yr surveys +26 seven yr surveys for a total 56 surveys required). Only three reconnaissance reforestation surveys conducted by a logging company exist in the records (Canfor 1987, 1989, 1991). While these "reports" lack text, study of the raw data and plot photographs shows complete failure of white spruce regeneration.

Provision \#41. Termination of the agreement did not waive the crown's right to legal action with respect to any breach of the conditions of the agreement.

\section{A Brief History of Logging of Timber Berth 408}

While the Denney Logging Company held the original 1956 agreement, they lost control in 1960 of both Timber Berths 408 and 378 due to financial problems. Swanson Lumber Company assumed the Timber Berth 408 lease in 1965 and began logging in 1966. Swanson was taken over by Canfor/High Level Forest Products in August of 1981. Canfor sold its mill in High Level to Daishowa in February 1990, but retained the logging rights to the berth in order to avoid re-negotiation of the agreement. During 1990-1991, Canfor sold the wood to Daishowa.

In the early days of the logging, trees were hand-felled with chainsaws. Trees were dragged to landings with rubber-tired skidders or tractors. Except for a few years in the 1960s when logging was year-round, cutting occurred only in winter (Olsen 1992). In the late 1980s, mechanical feller-bunchers replaced chainsaws. In most cases, all merchantable spruce were taken (or cut and left to rot). Small spruce were knocked over or destroyed by heavy machinery, as were snags and any deciduous trees or forests that were in the 
way. The clearcuts were "progressive", meaning simply that the clearcuts grew progressively larger with time.

Forestry Superintendent Rory Flanagan recalled that, from the outset, field inspections by park staff noted little or no natural regeneration of white spruce after logging (Flanagan 1992). Studies were requested decades ago to determine the failure of post-logging regeneration. No scientifically credible studies were conducted until just prior to shut down of the logging (Corns 1991; Pearson Timberline 1991).

While the agreement prescribed a logging rate 20 times the rates at which the forests could replace themselves, the actual situation was worse due to failure of natural regeneration in $93 \%$ of clearcuts (Timoney and Peterson in press; Pearson Timberline 1991). Succession in most cutblocks leads from an initial rose-raspberry association to a balsam poplar forest association (Timoney 1995). At the time of shutdown in March 1991, park staff estimated that all remaining oldgrowth spruce forests in the berth could have been logged within four years.

Between 1980 and 1990, an estimated minimum of 6,595 ha were logged. Such an estimate does not account for wood left or wasted, or for the common practice of cutting beyond cutblock boundaries. Nor does it count the tracts of noncommercial deciduous forest that were knocked down in pursuit of the spruce. Between 1980 and 1990, Canfor/High Level Forest Products cleared an average annual net profit of $\$ 1.5$ million (in "constant" 1990 dollars) (Dempster and Associates 1990).

As disastrous as the agreement proved, one of its provisions was sound: to log in a manner that encouraged natural regeneration. In practice, the terms of the agreement were not met nor was TB408 logged in accordance with the operating ground rules. Stelfox (1991) concluded that Canfor's operations in the 1980s did not comply with the wildlife-related regulations; the violations included "inadequate riparian buffers, excessively large cutovers, and significant amounts of large woody debris in watercourses." The fault lay with both the loggers and with Parks Canada. How could the logging have gone on for so long?

Parks Canada was "ignorant at the time in terms of environmental assessment" according to Mel Falk, Natural Resource Management Coordinator at the Prairie-Northern regional office in the early 1980s. Ross Dobson, who took over from Falk, notes that the logging records and files at regional and national offices were "a mess," and that bureaucratic ignorance hampered progress. Absence of a will to change meant that Falk's and Dobson's attempts at a proper environmental assessment of the logging met with little political support and were ignored.

Ignorance of ecologically sound forestry was another problem. Parks Canada lacked the expertise to regulate commercial logging. One chief park warden recommended to regional office that the loggers be encouraged to log to the banks of the Peace River “....since the banks of the Peace are high and in one or two seasons willow and poplar will hide the stumps... logging to the river produces a more natural landscape than would leaving a $100 \mathrm{~m}$ dark green strip on either side of the river" (Eddy 1982).

Lack of enforcement did not help matters. Swanson Logging ignored park requests for buffer strips along the Peace because, according to Swanson, they were not "beneficial for the regeneration or aesthetics of the river." (Olsen 1992). Frequently, warden reports and recommendations to the loggers to adhere to the terms of the agreement were ignored. Non-compliance was routine, logging was often carried out without prior approval, and tardy and incomplete documentation sent to the park officials by the loggers were all too common (Wood Buffalo National Park logging records and correspondence; Westhaver 1991; Olsen 1992). Cutblocks mapped as leaving riverside buffers were frequently cut down to the river (Pearson Timberline 1991). One sub-contractor for Swanson in 1975-76, was told by the logging company that he need not be concerned with violations since enforcement would not likely occur (Olsen 1992). Not only were the terms of the logging agreement flaunted, there is evidence that at least one company committed fraud and conflict of interest in its accounting (Hendry 1968).

Why then was the logging agreement renewed in 1983? While Parks Canada identified the logging as a non-conforming use, according to Ross Dobson, socio-economic considerations were the primary considerations in renewal of the lease. "Logging was not political back then," Dobson recalls. Former Superintendent of Wood Buffalo, Doug Stewart, notes that Parks Canada thought that the agreement was legal, and that compensation to the loggers after termination would have proved too expensive. Another factor in the government's failure to protect ecological integrity was the reluctance of government to "appear to be anti-business." Parks Canada senior officials thought that since "...government had leased all the timber in Wood Buffalo, they had a moral obligation to industry to continue until all the forests had been cut." (Dave McBurney, Parks Canada, Policy and Legislation Branch, pers. comm. 1995). Repeated breach of the logging agreement (provisions 12, 20, 27, 31, and 33) would have allowed the government to terminate the agreement at any time (termination provision \# 41). In spite of efforts by some dedicated staff in Parks, the logging agreement was renewed in 1983 (the same year the park was declared a World Heritage Site by UNESCO) with a new expiration date of May 2002.

\section{Enforcement, Non-Compliance, and the End of the Logging}

The complexion of the issue changed in 1988 when new staff came to Wood Buffalo. Incoming Chief Park Warden Lou Comin recalls thinking "how can we get rid of the logging?" Aware of the difficulties ahead, Comin also asked "if we can't get rid of it, how can we make it better?" In March 1990, Comin hired Steve Otway as his new assistant chief and gave him a clear directive: "Clean it up." Otway, a forester by training, worked with Superintendent Stewart and Comin to enforce the terms of the logging agreement and the Alberta Timber Harvest Planning and Operating Ground Rules rigidly and fairly, "No more, no less" according to Stewart. By the late 1980s, increasing public awareness of the Wood Buffalo logging brought intensified operations by Canfor in an attempt to liquidate the timber before adverse publicity might force an embarrassing political showdown. When interviewed about the logging, Canfor Vice-President Gordon Armstrong would only say that the logging was legal and the company's own business (Canadian Press 1990).

With management support, warden staff finally began to enforce the terms of the logging agreement in earnest. Park staff soon realized they were making a difference. Canfor took umbrage 
at the application of the Alberta ground rules. Otway remembers that when he informed Canfor that cutblocks (rather than progressive clearcuts), buffer zones, and holdbacks would be required he was "told off pretty good." "Many hostile meetings were held" with Canfor, recalls Superintendent Stewart. Environment Minister Jean Charest was solely concerned that Parks must treat the company with fairness. Review of the records indicates that Parks was fair, and patient. In the 1990-1991 logging season alone, a total of 83 offenses were recorded by inspectors (Westhaver 1991). The most frequent violations were for damage to reserve trees and advance growth, and for wastage of timber.

By September 1991, with effective enforcement and growing public support, park staff became hopeful that the logging might eventually be shut down. Preliminary discussions to end the logging took place between Parks Canada and Canfor. In the event of a failure of negotiations, Parks Canada was prepared to go to court, but Canfor/Daishowa/High Level Forest Products were most anxious to avoid the attendant publicity (D. Stewart, pers. commun. 1994). Termination discussions were made moot on 8 June 1992 when a federal court, responding to a challenge by the Sierra Legal Defence Fund on behalf of the Canadian Parks and Wilderness Society (CPAWS), ruled that the logging in Wood Buffalo contravened the National Parks Act, and was therefore illegal. There was never a legal basis for logging in Wood Buffalo.

After the agreement was nullified in court, the loggers maintained they had been wrongly deprived of millions of dollars of profit from the timber berth. For reasons that may never be revealed, the Mulroney cabinet chose to pay the logging concern $\$ 2.5$ million for an estimated remnant $30 \mathrm{~km}^{2}$ of old-growth forest to be logged under an illegal agreement in a national park.

Why did the federal government pay the logging consortium? When one of the government negotiators was asked the response was that it is "a long story" with "lots of political sensitivity... lots of things lurking in the background." A warning not to probe into the government's role in the logging was also given. Conversely, repeated requests to Canfor for information regarding their logging of Wood Buffalo, the out-ofcourt settlement and negotiations, and the decision to avoid a press release after negotiations were complete, have all been met with silence.

How can the federal government pay $\$ 2.5$ million compensation for termination of an illegal agreement? Perhaps this is why the negotiations and payment were secret, and a press release never issued. Perhaps the whole truth may one day be known.

\section{The Future}

In TB408, median spruce stocking and density in the cutblocks $=36.4 \%$ and $848 \mathrm{ha}^{-1}$, most of which are seedlings and advance growth ( $35 \%$ stocking, density $\left.800 \mathrm{ha}^{-1}\right)$. Median spruce sapling and tree stocking and density in the cutblocks $=0 \%$ and $0 \mathrm{ha}^{-1}$. Median spruce stocking in undisturbed spruce and mixedwood forests in TB408 $=76 \%$; in order to achieve this pre-logging stocking level, $93 \%$ of the cutblocks will require planting (Timoney and Peterson, in press).

If Heritage Canada is to uphold its legal mandate of restoring ecological integrity, the spruce regeneration costs may total $\$ 9.3$ million over 9300 ha of degraded land. Significant savings could be achieved by planting fewer spruce in areas supporting some natural regeneration. At the minimum, \$5 mil- lion would be needed for Wood Buffalo to avoid a potential law suit for failure to uphold the public trust. Restoration of selected stream channels, bridge removal, and clean-up will add another $\$ 500,000$. Restoration plans have been prepared for the berth (Geowest 1993; Timoney et al. 1994), and a longterm monitoring program established (Timoney and Robinson 1995). The plans outline the collection of seed, growing of seedlings, planting and follow-up work, restoration of stream channels, removal of bridges, etc. No restoration plans have been prepared for the other five timber berths. The job will not be done until the fabric of the ecosystem is restored. "It will be a long process to restore the berth," Comin realizes, "but in the end it will be worth it."

Will a government committed to budget cuts fund the work? To date, all attempts to secure funds to begin the restoration have been rejected by government. CPAWS President Harvey Locke, while "happy that the logging is over", quickly adds that CPAWS "will not be satisfied till ecological restoration is complete." In response to a letter from the President of the Alberta Wilderness Association regarding concern for the future of TB408, Canadian Heritage Minister Michel Dupuy wrote: [1] "I am pleased to inform you that the Department has begun work to restore the logged area... [2] research ... will determine the effect of fire on seeds and plant survival... [3] The Park has already purchased seed for planting... [4] work to be carried out over the next two to three years." (Dupuy 1995). The actual situation is this: [1] No restoration work has begun; [2] No such research has been conducted nor is planned; [3] The park has purchased $5.1 \mathrm{~kg}$ (\$2000.) of white spruce seed, $20 \%$ of total seeds needed, and $0.036 \%$ of total expenditures required if we assume 5 million seedlings; [4] Requests for funding for restoration work have been all rejected by Canadian Heritage (e.g., Timoney et al. 1994). The federal government has yet to commit any funds toward restoration of any of the logged areas of Wood Buffalo National Park.

It is little wonder that mistrust of government and the forest industry is pervasive. Government must not be allowed to ignore its legal responsibilities. Presently the government stance has been to attempt to forget the logging of Wood Buffalo National Park, both to avoid recognition of mismanagement and restoration costs. And what of the logging companies? Should they receive millions of dollars in profits from logging in a national park, repeatedly breach the terms of an agreement, receive $\$ 2.5$ million "compensation", then have no responsibilities?

\section{Conclusions}

(1) The logging of Wood Buffalo National Park was illegal from the outset.

(2) Parks Canada, in its 23 year tenure (1969-1991) as public guardian of the forests of Wood Buffalo, failed to uphold The National Parks Act, and failed to enforce the terms of the Timber Berth 408 logging agreement and the timber operating ground rules.

(3) Until 1988, the federal government's actions in overseeing the logging of Wood Buffalo were characterized by mismanagement.

(4) The various logging companies involved repeatedly breached the terms of the logging agreement and the timber operating ground rules. 
(5) The logging has created conditions where natural regeneration of white spruce is impossible. Active restoration is required. Costs should be shared by both the responsible logging companies and the federal government.

(6) Changes in Parks staff and increased public awareness and political pressure culminated in a federal court decision that brought an end to the illegal logging of Wood Buffalo National Park.

\section{Acknowledgments}

Ben Gadd provided expert editorial criticism. Thanks to all people who gave interviews. Grant Corey assisted with office tasks.

\section{References}

Annas, R.M. 1977. Boreal ecosystems of the Fort Nelson area of northeastern British Columbia. Ph.D. thesis, University of British Columbia, Vancouver, BC. 409 p.

Anonymous. 1983. Agreement between Her Majesty The Queen and Canadian Forest Products Ltd. regarding Timber Berth No. 408, Wood Buffalo National Park. Wood Buffalo National Park, Ft. Smith, N.T. Document on file.

Anonymous. 1990. Alberta timber harvest planning and operating ground rules. Alberta Forestry, Lands and Wildlife, Edmonton, AB. Canadian Press. 1990. Feds can't stop logging in park. News/North, 17 December 1990, p. A22.

Canfor. 1987, 1989, 1991. Vegetation surveys, Timber Berth 408, Wood Buffalo National Park. Wood Buffalo National Park, Ft. Smith, N.T. Raw data and photographs on file.

Corns, I.G.W. 1991. Logging impacts on white spruce floodplain communities in Timber Berth 408 of Wood Buffalo National Park. Wood Buffalo National Park, Ft. Smith, N.T. Report.

Dempster and Associates. 1990. Timber supply appraisal in Timber Berth 408. Wood Buffalo National Park, Ft. Smith, N.T. Report.

Dupuy, M. 1995. Letter to Cliff Wallis, President, Alberta Wilderness Association from Michel Dupuy, Minister of Canadian Heritage, 22 March 1995. Letter on file.

Eddy, R. 1982. Letter to Director, Parks Canada Prairie Regional Office (Winnipeg) Re: Proposed Timber Agreement-Swansons; from R. Eddy, Acting Chief Park Warden, Wood Buffalo National Park, Ft. Smith, N.T. Letter on file.

Fairbarns, M. 1991. Old-growth in the boreal mixedwood forest section. Alberta Forestry, Lands and Wildlife, Edmonton. Technical report. Farr, D. 1993. Bird abundance in spruce forests of west central Alberta: the role of stand age. pp. 55-62 In: Birds in the Boreal Forest. H. Kuhnke, Ed. Proc. of a workshop, Prince Albert, Saskatchewan, Northem Forestry Centre, Edmonton, AB.

Flanagan, R. 1992. History and longing. Wilderness Alberta 22(2): 18-19.

Francis, J. and K. Lumbis. 1979. Habitat relationships and management of terrestrial birds in northeastern Alberta. Alberta Oil Sands Envir. Res. Prog., AOSERP Rep. 78, 365 p.

Geowest. 1993. Ecosystem restoration plan for Timber Berth 408 in Wood Buffalo National Park. Wood Buffalo National Park, Ft. Smith, N.T. Report.

Hendry, J. 1968. Wood Buffalo National Park forestry study. Economic Staff Group, Dept. of Indian Affairs and Northern Development, Ottawa. Report.
Lothian, W.F. 1976. A History of Canada's National Parks, Volume 1. Parks Canada, Dept. of Indian Affairs and Northern Development, Ottawa, ON.

Marshall, V.G. 1993. Sustainable forestry and soil fauna diversity. pp. 239-248: In Our living legacy. M.A. Fenger, E.H. Miller, J.A. Johnson and E.J.R. Williams, Eds. Proc. of a Symposium on Biological Diversity, Royal British Columbia Museum, Victoria, BC. Meslow, E.C., C. Maser and J. Verner. 1981. Old-growth forests as wildlife habitat. North Amer. Wildl. Conf. 46: 329-335.

Nanson, G.C. and H.F. Beach. 1977. Forest succession and sedimentation on a meandering-river floodplain, northeast British Columbia, Canada. J. Biogeogr. 4: 229-251.

National Parks Service. 1930. An Act Respecting National Parks. Dept. of Northern Affairs and National Resources, National Parks Branch, National Parks Service, Ottawa, ON.

Olsen, R. 1992. Timber Berth 408 Historical Overview. Wood Buffalo National Park, Ft. Smith N.T. Operational report 92-04/WB. Pearson Timberline. 1991. Post-harvest surveys and natural reforestation assessment in T.B. 408, Wood Buffalo National Park, for the period 1981-1990. Wood Buffalo National Park., Ft. Smith, NT Report. Peterson, E.B. 1981. Alluvial ecosystems. Mackenzie River Basin Study, Report Suppl. 2, Mackenzie River Basin Committee, Ottawa, ON. 129 p.

Potyondi, B. 1979. Wood Buffalo National Park: an historical overview and source study. Parks Canada, Manuscript Report \#345. Ottawa, ON.

Ray, R.G. 1961. Forest inventory of the Lower Peace and Athabasca Rivers in Wood Buffalo National Park. Dept. of Forestry, Administration Branch, Forest Management Paper No. 3. Ottawa, ON. Revised 1964.

Stelfox, B. 1991. Effects of logging operations on wildlife communities in Timber Berth 408 of Wood Buffalo National Park. Wood Buffalo National Park, Ft. Smith, NT. Report.

Swanson Lumber Company. 1981. Forest management plan, Timber Berth 408, Wood Buffalo National Park. Wood Buffalo National Park, Ft. Smith, N.T. Report.

Timoney, K.P. 1995. Peace like a river: ecological studies and restoration in Wood Buffalo National Park. pp. 490-500 In: Ecosystem monitoring and protected areas. T.B. Herman, S. BondrupNielson, J.H.M. Willison and N.W.P. Munro, Eds. Proc. of the Second Intern. Conf. on Science and the Manage. of Prot. Areas, Dalhousie Univ., Halifax, NS.

Timoney, K.P., T. Cochlin and J. Mercer. 1994. Timber Berth 408 Restoration Plan. Parks Canada request for funding to regional office, Project \# 67031 (rejected). Wood Buffalo National Park, Ft. Smith, N.T. Document on file.

Timoney, K.P. and A.L Robinson. 1996. Old-growth white spruce and balsam poplar forests of the Peace River Lowlands, Wood Buffalo National Park, Canada: development, structure, and diversity. Forest Ecology and Management, 81: 179-196.

Timoney, K.P. and G. Peterson, 1996. Failure of natural regeneration after clearcut logging in Wood Buffalo National Park, Canada. Forest Ecology and Management (in press).

Westhaver, A. 1991. Timber Berth 408 1990/91 year end report. Wood Buffalo National Park, Ft. Smith, N.T. Operational report 9107/WB.

Westworth and Associates. 1990. Significant natural features of the eastern boreal forest region of Alberta. Alberta Forestry, Lands and Wildlife, Edmonton, Technical Report, 147 p. 